\title{
Bioconversion of lignocellulose: inhibitors and detoxification
}

\author{
Leif J Jönsson ${ }^{1 *}$, Björn Alriksson ${ }^{2}$ and Nils-Olof Nilvebrant ${ }^{3}$
}

\begin{abstract}
Bioconversion of lignocellulose by microbial fermentation is typically preceded by an acidic thermochemical pretreatment step designed to facilitate enzymatic hydrolysis of cellulose. Substances formed during the pretreatment of the lignocellulosic feedstock inhibit enzymatic hydrolysis as well as microbial fermentation steps. This review focuses on inhibitors from lignocellulosic feedstocks and how conditioning of slurries and hydrolysates can be used to alleviate inhibition problems. Novel developments in the area include chemical in-situ detoxification by using reducing agents, and methods that improve the performance of both enzymatic and microbial biocatalysts.
\end{abstract}

\section{Review}

\section{Background}

Lignocellulose provides an abundant renewable resource for production of biofuels, chemicals, and polymers [1-3]. Biorefineries, in which lignocellulosic biomass is converted to various commodities, are likely to become increasingly important in future society as complement and alternative to the oil refineries of today. Commodities produced from renewable resources offer an alternative to products based on dwindling supplies of petroleum and permit a move towards improved energy security and decreased impact on the environment. Lignocellulosic feedstocks include residues from agriculture and forestry, energy crops, and residues from biorefineries and pulp mills. Lignocellulosic biomass can contribute significantly to the future global energy supply without competition with increasing food demand for existing arable land [4].

Liquid biofuels include bioalcohols, such as ethanol and butanol, and biodiesel. Ethanol is the most important liquid biofuel of today. Bioalcohols are manufactured in fermentation processes, in which microbial biocatalysts, yeasts or bacteria, convert sugars to alcohols. The ethanol that is used today is mainly manufactured from sugar or starch-based raw materials. However, very large-scale use of bioalcohols in the energy sector will require production

\footnotetext{
* Correspondence: leif.jonsson@chem.umu.se

'Department of Chemistry, Umeå University, Umeå SE-901 87, Sweden

Full list of author information is available at the end of the article
}

from lignocellulosic feedstocks [1-5], which have the added benefit that they are not used for food. This review focuses on biocatalyst inhibitors formed during acidic thermochemical pretreatment of lignocellulosic feedstocks, and how conditioning of slurries and hydrolysates can be used to alleviate inhibition problems connected with hydrolytic enzymes and the yeast Saccharomyces cerevisiae.

\section{Lignocellulose and pretreatment of lignocellulosic feedstocks}

Lignocellulosic feedstocks mainly consist of cellulose, hemicellulose, and lignin [6,7]. Cellulose is an unbranched homopolysaccharide consisting of D-glucopyranosyl units. Hemicelluloses are branched heteropolysaccharides consisting of both hexose and pentose sugar residues, which may also carry acetyl groups. The third main component, lignin, consists of phenylpropane units linked together by different types of interunit linkages of which ether bonds are the most common. Lignocellulose polysaccharides are hydrolyzed to provide the monosaccharides used by microbial biocatalysts in fermentation processes. The crystalline parts of the cellulose are more resistant to hydrolysis than are the amorphous parts. Compared to starch, the polysaccharides of lignocellulose are more resistant to hydrolysis. Furthermore, woody biomass is generally more resistant to degradation than other types of lignocellulose. Softwood is typically more difficult to hydrolyze than hardwood or agricultural residues [8-12]. 
Hydrolysis of cellulose can be catalyzed by using strong inorganic acids or hydrolytic enzymes, including cellulases $[13,14]$. Acid hydrolysis of cellulose requires severe conditions. Enzymatic hydrolysis is often considered as the most promising approach for the future [5]. Lignocellulosic biomass intended for production of liquid biofuels is typically pretreated in an acidic thermochemical process step to increase the susceptibility of the cellulose to enzymatic hydrolysis $[5,9,12]$. The pretreatment usually degrades the hemicellulose leading to the formation of products such as pentose and hexose sugars, sugar acids, aliphatic acids (primarily acetic acid, formic acid and levulinic acid), and furan aldehydes [5-hydroxymethylfurfural (HMF) and furfural] (Figure 1). After hydrolysis of lignocellulose polysaccharides, lignin remains as a solid residue, although a minor part is degraded to phenolics and other aromatic compounds (Figure 1). Sugars derived from hemicelluloses will account for a substantial part of the total sugar and it is desirable that they are included in the subsequent fermentation step. The monosaccharides obtained through the hydrolysis process are then fermented by microbial catalysts to the desired product, most commonly ethanol produced with the yeast $S$. cerevisiae.

Hydrolysis and fermentation can be performed separately (separate hydrolysis and fermentation; SHF) or simultaneously (simultaneous saccharification and fermentation; $\mathrm{SSF}$ ). Consolidated bioprocessing (CBP) refers to a process in which the fermenting microorganism also contributes by producing cellulolytic enzymes [15].

\section{Inhibitors of enzymatic and microbial biocatalysts}

The generation of by-products from the pretreatment is strongly dependent on the feedstock and the pretreatment method. Substances that may act as inhibitors of microorganisms include phenolic compounds and other aromatics, aliphatic acids, furan aldehydes, inorganic ions, and bioalcohols or other fermentation products. Examples of inhibitory fermentation products are ethanol and butanol. As most microorganisms, S. cerevisiae is inhibited by butanol concentrations in the range $1-2 \%(\mathrm{v} / \mathrm{v})$ [16], but it is able to withstand much higher concentrations of ethanol. In high-gravity alcoholic fermentations, S. cerevisiae produces ethanol concentrations of $17 \%(v / v)$ or higher [17]. Hydrolytic enzymes are inhibited by their products, i.e. sugars such as cellobiose and glucose [18], by fermentation products such as ethanol $[19,20]$, and by phenolic compounds [21].

\section{Aromatic compounds}

A large number of different phenolic compounds are formed from lignin during acid-catalyzed hydrolysis or pretreatment of lignocellulose. Phenolic compounds and other aromatics are formed during pretreatment regardless of whether an acid catalyst is added to the reaction [22]. Carboxylic acids formed during the pretreatment will contribute to the formation of an acidic environment. Furthermore, some extractives are phenolic compounds [6,7]. Formation of phenolic compounds from sugars is another possibility [23],

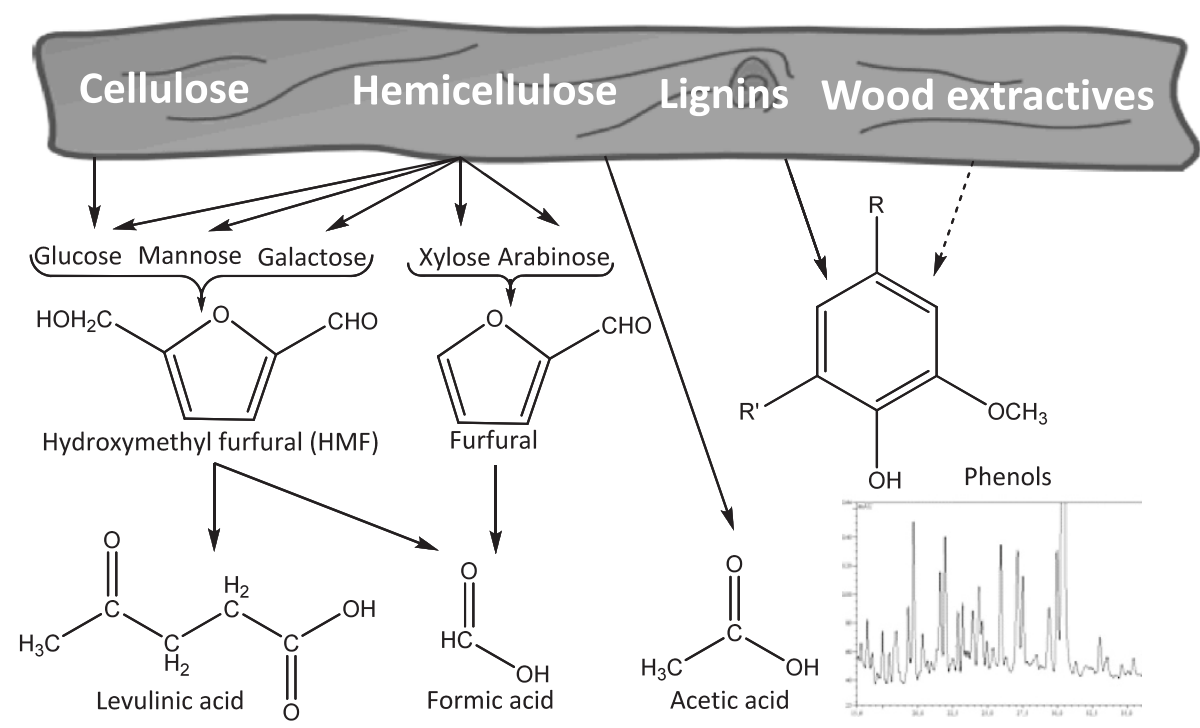

Figure 1 Formation of inhibitors. Scheme indicating main routes of formation of inhibitors. Furan aldehydes and aliphatic acids are carbohydrate degradation products, while lignin is the main source of phenolic compounds, as indicated by guaiacyl (4-hydroxy-3methoxyphenyl) and syringyl (4-hydroxy-3,5-dimethoxyphenyl) moieties found in many phenolics. While the contents of furan aldehydes and aliphatic acids are relatively easy to determine, the quantification and identification of phenolic compounds remain challenging. The insert shows the variety of peaks representing phenolic compounds found in a hydrolysate of Norwegian spruce, as indicated by analysis using liquid chromatography-mass spectrometry (LC-MS). 
although the significance of this route remains to be investigated.

Different analytical techniques, primarily gas chromatography-mass spectrometry (GC-MS) and liquid chromatography-mass spectrometry (LC-MS), have been used to identify specific aromatic compounds in acidic hydrolysates from various kinds of lignocellulosic feedstocks, such as corn stover [24-26], oak [27], pine $[26,28,29]$, poplar [24,30-32], spruce [33-35], sugarcane bagasse [22], switchgrass [24], and willow [36]. In addition, aromatic degradation products in hydrolysates produced by alkaline methods have been investigated $[26,37]$. The large number and the diversity of the aromatic compounds found in different lignocellulose hydrolysates (Figure 1) make identification and quantification of separate compounds complicated. Group analysis of phenolic compounds offers an alternative approach. GC-MS has been used to estimate the total amount of phenols in lignocellulose hydrolysates $[33,36]$. The total amount of phenols in a spruce wood hydrolysate was determined spectrophotometrically by using the Prussian Blue method [33]. Persson et al. [34] compared the Prussian Blue method with another spectrophotometric method, based on Folin-Ciocalteu's reagent, and found that the latter gave more reliable results with respect to analysis of phenolic compounds in the hydrolysate. A peroxidase-based biosensor was also tested, as an alternative to the spectrophotometric methods [34]. Furthermore, a method for group analysis of phenols by high-performance liquid chromatography (HPLC) has also been used [38]. Although the FolinCiocalteu method is the most convenient approach to analyze the total phenolic contents in lignocellulose hydrolysates, it should be avoided in experiments with redox reagents (such as reduced sulfur compunds including dithionite, dithiothreitol, and sulfite), in which the HPLC method serves as a better option [39]. It should also be noticed that phenol analysis using the Folin-Ciocalteu reagent is related to the Lowry method for determination of the total protein content [40] and that it is therefore sensitive to potential media components such as hydrolytic enzymes, cell extracts, and hydrolyzed protein.

The effects of phenolics and other aromatic compounds, which may inhibit both microbial growth and product yield, are very variable, and can be related to specific functional groups $[30,41]$. In many cases, the mechanism of toxicity has not been elucidated. One possible mechanism is that phenolics interfere with the cell membrane by influencing its function and changing its protein-to-lipid ratio [42]. S. cerevisiae can convert some inhibitory phenolics to less toxic compounds. For instance, coniferyl aldehyde is reduced to coniferyl alcohol and dihydroconiferyl alcohol [41].
The role of phenolic inhibitors has been investigated using enzymic catalysts that specifically affect phenolic compounds without changing the concentrations of other inhibitors, such as aliphatic acids and furan aldehydes [33,36,43-45]. Enzymes, such as laccases and peroxidases, oxidize phenols to radicals that undergo coupling to larger molecules that are less toxic to fermenting microbes such as yeast [36].

Phenolic compounds are also investigated with regard to inhibition of enzymatic hydrolysis of cellulose [21]. Experiments with phenols suggest that one way in which they affect proteins is by inducing precipitation [46].

\section{Aliphatic acids}

Lignocellulose hydrolysates contain aliphatic acids, such as acetic acid, formic acid, and levulinic acid. Acetic acid is formed primarily by hydrolysis of acetyl groups of hemicellulose, while formic acid and levulinic acid arise as acid-catalyzed thermochemical degradation products from polysaccharides (Figure 1). Formic acid is a degradation product of furfural and HMF (5-hydroxymethylfurfural), while levulinic acid is formed by degradation of HMF [47]. The pKa value of formic acid (3.75) is considerably lower than those of acetic acid (4.76) and levulinic acid (4.64). The toxic effect on S. cerevisiae is attributed to the undissociated form and increases in the order acetic acid < levulinic acid < formic acid. Inhibition of yeast was found to be apparent at concentrations exceeding $100 \mathrm{mM}$ [48]. However, lower concentrations than $100 \mathrm{mM}$ gave higher ethanol yields than fermentations with no aliphatic acids included [48]. The contents of aliphatic acids in slurries and hydrolysates vary strongly depending on the feedstock and the severity of the pretreatment. Feedstocks with high content of acetylated xylan, typically agricultural residues and hardwood, give higher concentrations of aliphatic acids than softwood. The total content of aliphatic acids in softwood hydrolysates is often below $100 \mathrm{mM}$ and consequently beneficial for the ethanol yield rather than harmful $[48,49]$.

Undissociated acids enter the cell through diffusion over the cell membrane and then dissociate due to the neutral cytosolic $\mathrm{pH}$ [50]. The dissociation of the acid leads to a decrease in the intracellular $\mathrm{pH}$, which may lead to cell death. Alternatively, it may lead to increased ethanol yield at the expense of biomass formation as a consequence of the cell's attempt to maintain a constant intracellular $\mathrm{pH}$ by pumping out protons through the plasma membrane ATPase [51-53].

A group of compounds that can be mentioned in this context are uncouplers, i.e. amphiphilic molecules that dissolve in the inner mitochondrial membrane of eukaryotic cells and that have the ability to transfer protons across the membrane. By disrupting the proton gradient over the inner mitochondrial membrane, they 
disconnect the linkage between the respiratory chain and the oxidative phosphorylation that regenerates ATP from ADP. This mechanism differs from that proposed for aliphatic acids like acetic acid, as it inhibits the regeneration of ATP in mitochondria rather than stimulate the consumption of ATP at the plasma membrane. Some aromatic carboxylic acids may act as uncouplers, as has been shown in experiments with plant cells and salicylic acid [54], a compound that is also found in lignocellulose hydrolysates [26,36]. Another aromatic carboxylic acid, $p$-hydroxybenzoic acid, which is common in lignocellulose hydrolysates, did not exhibit the uncoupling effect observed for salicylic acid [54].

\section{Furan aldehydes}

The furan aldehydes furfural and HMF, which also are commonly found in lignocellulose hydrolysates, are formed by dehydration of pentose and hexose sugars, respectively (Figure 1). Furfural and HMF inhibit the growth of yeast and decrease ethanol yield and productivity $[48,55,56]$. Under anaerobic conditions, S. cerevisiae can convert furfural to furfuryl alcohol $[57,58]$ and HMF to 2,5-bis-hydroxymethylfuran [59]. Reduction of furfural has been linked to the co-factor NADH, while reduction of HMF has been found to be associated with consumption of NADPH [60]. A moderate addition of furfural to the growth medium was found to lead to increased ethanol yields for recombinant xylose-utilizing $S$. cerevisiae transformants [60]. This can be explained by the reduction of furfural to furfuryl alcohol, which will lead to a decreased formation of the undesirable by-product xylitol and an increased formation of ethanol. Model fermentations with furan aldehydes added to the medium suggest that yeast can tolerate quite high concentrations of furan aldehydes [48,61]. Martinez et al. [62] noticed that it took an addition of three times the original concentrations of the furan aldehydes to restore the inhibition of $E$. coli by a detoxified bagasse hydrolysate. These observations suggest that the inhibition might be due to other inhibitors present in the hydrolysate, other yet unidentified compounds, or perhaps to synergistic effects involving furan aldehydes. The capability of the microorganism to reduce furan aldehydes to the less toxic corresponding alcohols during fermentation in a bioreactor is sometimes referred to as in-situ detoxification [63]. The concept of biological in-situ detoxification is based on the presumption that it is the mere presence of the inhibitory substance that is the problem, rather than its bioconversion.

\section{Inorganic compounds}

Inorganic ions that are present in lignocellulose hydrolysates originate from the lignocellulosic feedstocks, from chemicals added during pretreatment, conditioning and hydrolysis, and possibly from process equipment. The addition of salts results in a higher osmotic pressure, which may result in inhibitory effects $[64,65]$. At moderate concentrations, there is a possibility that inorganic ions enhance ethanol production in a similar way as moderate concentrations of aliphatic acids do. The proposed mechanism is increased demand of ATP due to increased transport over the plasma membrane. Extra ATP is acquired by an increased ethanol production at the expense of biomass formation.

S. cerevisiae is relatively salt tolerant compared to other yeasts, such as Schizosaccharomyces pombe and Scheffersomyces (Pichia) stipitis, but less tolerant than several Candida species [64]. In glucose-based medium, S. cerevisiae is capable to grow in a $1.5 \mathrm{M}$ solution of sodium chloride. However, a more important factor than the absolute concentration of sodium is the intracellular ratio of $\mathrm{Na}^{+} / \mathrm{K}^{+}$, which preferably should be kept low. Maiorella et al. [66] investigated the effects of different salts on $S$. cerevisiae and found that the inhibition decreased in the following order: $\mathrm{CaCl}_{2},\left(\mathrm{NH}_{4}\right)_{2} \mathrm{SO}_{4}>$ $\mathrm{NaCl}, \mathrm{NH}_{4} \mathrm{Cl}>\mathrm{KH}_{2} \mathrm{PO}_{4}>\mathrm{MgCl}_{2}>\mathrm{MgSO}_{4}>\mathrm{KCl}$.

\section{Other inhibitory effects}

Ethanol generated during fermentation inhibits viability, growth, glucose transport systems, and proton fluxes of S. cerevisiae. The yeast plasma membrane is affected with respect to permeability, organization, and lipid composition [67]. However, the ethanologenic microbes S. cerevisiae and Zymomonas mobilis can tolerate ethanol concentrations up to 18 and $12 \%$, respectively [68]. The engineering of microbes for improved resistance to bioalcohols and other biofuels has recently been reviewed [16].

Potential synergistic effects of inhibitors have been studied in experiments with yeast and bacteria [69-71]. The results of these studies indicate synergistic effects of combinations of acids and furan aldehydes, as well as of combinations of different phenolics.

\section{Strategies to counteract inhibition problems}

Several alternative measures can be taken to avoid problems caused by inhibitors. The concentrations of inhibitors and sugars in hydrolysates depend on the feedstock as well as on the conditions during pretreatment and hydrolysis $[9,48]$. Therefore, one possibility is to select less recalcitrant feedstocks and to utilize mild pretreatment conditions. However, it is desirable to utilize different varieties of lignocellulose if production of commodities from renewables should make a major impact on the market for fuels, chemicals, and materials. Furthermore, production of bulk chemicals is yield dependent, which implies that it is not reasonable to accept a poor sugar yield, and consequently a poor 
Table 1 Techniques for detoxification of lignocellulose hydrolysates and slurries

\begin{tabular}{|c|c|c|}
\hline Technique & Procedure & Example $^{a}$ \\
\hline \multirow[t]{2}{*}{ Chemical additives } & Alkali [such as $\mathrm{Ca}(\mathrm{OH})_{2}, \mathrm{NaOH}, \mathrm{NH}_{4} \mathrm{OH}$ ] & {$[76,77]$} \\
\hline & Reducing agents [such as dithionite, dithiothreitol, sulfite] & [39] \\
\hline \multirow[t]{2}{*}{ Enzymatic treatment } & Laccase & {$[36,45]$} \\
\hline & Peroxidase & [36] \\
\hline \multirow[t]{2}{*}{ Heating and vaporization } & Evaporation & [33] \\
\hline & Heat treatment & [78] \\
\hline \multirow[t]{3}{*}{ Liquid-liquid extraction } & Ethyl acetate & {$[24,75]$} \\
\hline & Supercritical fluid extraction [such as supercritical $\mathrm{CO}_{2}$ ] & [34] \\
\hline & Trialkylamine & [79] \\
\hline \multirow[t]{3}{*}{ Liquid-solid extraction } & Activated carbon & [80] \\
\hline & lon exchange & {$[38,81]$} \\
\hline & Lignin & [82] \\
\hline \multirow[t]{3}{*}{ Microbial treatment } & Coniochaeta ligniaria & {$[83,84]$} \\
\hline & Trichoderma reesei & {$[33,85]$} \\
\hline & Ureibacillus thermosphaericus & {$[86]$} \\
\hline
\end{tabular}

${ }^{a}$ The table includes one or two examples of each procedure (references are not exhaustive). Dilution, washing of solid fractions, and techniques based on the fermenting microbe are not included.

overall product yield, due to the use of insufficient pretreatment conditions.

It is also possible to design the fermentation process to avoid problems with inhibition, for example by using SSF to avoid inhibition of cellulolytic enzymes by sugars, or by using fed-batch or continuous cultivation rather than batch processes [72]. High yield and productivity, high product titer, and possibilities to recirculate process water are, however, important aspects of the chosen design. Ethanol production from diluted hydrolysates with low sugar content is associated with a high operating cost due to a more expensive distillation process [68].

There is a variety of different chemical, biological and physical methods that can be used to detoxify slurries and hydrolysates $[33,73,74]$. Approaches that have been studied include overliming and treatments with other chemicals, liquid-liquid extraction, liquid-solid extraction, heating and evaporation, and treatments with microbial and enzymatic biocatalysts (Table 1). Comparisons of different methods for detoxification, or conditioning, indicate that they differ significantly with respect to effects on hydrolysate chemistry and fermentability [33,75]. A common objection against detoxification is based on the assumption that it would require a separate process step.

There are a number of strategies that concern the fermenting microorganism. The use of large inocula decreases inhibition problems $[55,73,75]$. However, the use of large inocula is considered to be a less attractive solution in an industrial context [87]. Using a large inoculum would be a possibility if the microorganism can be recirculated and reused at a reasonable cost. However, if the used fermentation broth contains a lot of solids, the separation of the microorganism could become a tedious task. This is the case in SSF processes, and as a consequence the use of fresh inocula is considered instead of recycling the microorganism [88].

Other possibilities that target the microorganism include selection of microbial species and strains that exhibit resistance to inhibitors. Adaptation of the microorganism to an inhibiting environment, possibly after inducing variation by mutagenesis, serves as an alternative option. Furthermore, genetic engineering can be employed to obtain transformed hyperresistant microbes. S. cerevisiae has been engineered for increased resistance to fermentation inhibitors by overexpression of enzymes conferring improved resistance to

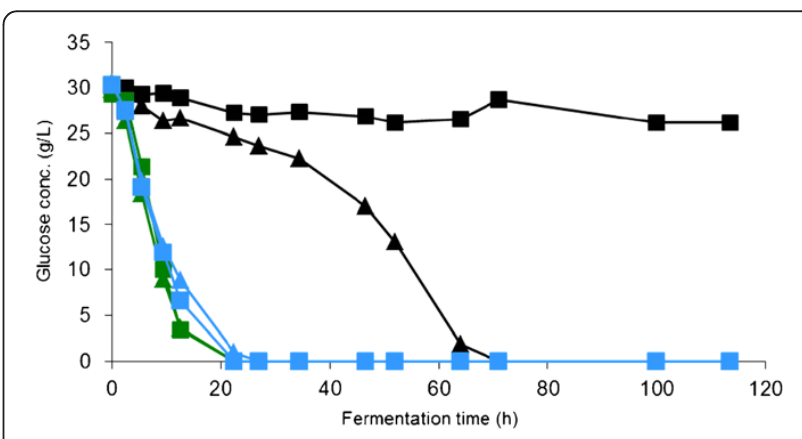

Figure 2 Effects of genetic engineering for hyperresistance and chemical detoxification through alkaline treatment. Ethanol production by S. cerevisiae (control transformant and transformant overexpressing Yap1 [95]): in spruce hydrolysate medium (black triangle, Yap1 transformant; black square, Control transformant), in alkali-detoxified spruce hydrolysate (green triangle, Yap1 transformant; green square, Control transformant), and in inhibitorfree medium (blue triangle, Yap1 transformant; blue square, Control transformant). 
phenolics [89,90], furan aldehydes [91,92], and aliphatic acids $[93,94]$. Furthermore, overexpression of a transcription factor, Yap1 [95], and of multidrug-resistance proteins [95] has also generated hyperresistant S. cerevisiae transformants. In some of these cases, hyperresistance to lignocellulose hydrolysates has also been demonstrated $[89,90,95]$.

Most of the studies on inhibition have had focus on the fermenting microorganism, while strategies that decrease inhibition of enzymes so far have received relatively little attention. Since most enzymatic hydrolysis processes involve mixtures of a pretreatment liquid and a solid cellulosic material, there are good reasons to take enzyme inhibition into account. Chemical detoxification, a powerful strategy to deal with inhibitor problems which also addresses enzyme inhibition, will be considered in more detail below.

\section{Chemical treatment}

Although methods such as liquid-liquid extraction, ion exchange, and treatment with biocatalysts remain

Table 2 Effects of alkaline treatment on monosaccharides and ethanol production

\begin{tabular}{|c|c|c|c|c|}
\hline System studied & Detoxification conditions & Improvement in fermentability & Effect on inhibitors and sugar & Reference \\
\hline \multirow[t]{5}{*}{ Spruce hydrolysate. S. cerevisiae } & $\mathrm{Ca}(\mathrm{OH})_{2} \mathrm{pH} 10,1 \mathrm{~h}$ & $\begin{array}{l}\mathrm{BEY}^{\mathrm{a}}=98 \% \\
\mathrm{BEY}^{\mathrm{a}}\left(\text { untreated }^{\mathrm{b}}\right)=71 \%\end{array}$ & $\begin{array}{l}\text { Furan aldehydes, decrease: } ~ 21 \% \\
\text { Phenols, decrease: } ~ 19 \%\end{array}$ & {$[33]$} \\
\hline & & $\mathrm{BEY}^{\mathrm{a}}\left(\right.$ reference $\left.^{\mathrm{c}}\right)=100 \%$ & Sugar, decrease: $\sim 4 \%^{\mathrm{d}}$ & \\
\hline & $\mathrm{NaOH}$ pH 10, $1 \mathrm{~h}$ & $B E Y^{a}=94 \%$ & Furan aldehydes, decrease: 18\% & \\
\hline & & $B E Y^{a}\left(\right.$ untreated $\left.^{b}\right)=71 \%$ & Phenols, decrease: 18\% & \\
\hline & & $B E Y^{a}\left(\right.$ reference $\left.^{c}\right)=100 \%$ & Sugar, decrease: $\sim 4 \%^{\mathrm{d}}$ & \\
\hline \multirow[t]{2}{*}{ Bagasse hydrolysate. E. coli } & $\mathrm{Ca}(\mathrm{OH})_{2} \mathrm{pH} 9,60^{\circ} \mathrm{C}, 0.5 \mathrm{~h}$ & $\begin{array}{l}\mathrm{Q}_{(24 \mathrm{~h}):}^{\mathrm{e}} \sim 1.3 \mathrm{~g} / \mathrm{Lh} \\
\text { No reference fermentation }\end{array}$ & $\begin{array}{l}\text { Furan aldehydes, decrease: } \sim 69 \% \\
\text { Phenols, decrease: } \sim 35 \% \\
\text { Sugar, decrease: } \sim 15 \%^{f}\end{array}$ & {$[97]$} \\
\hline & $\mathrm{Ca}(\mathrm{OH})_{2} \mathrm{pH} 10,60^{\circ} \mathrm{C}, 0.5 \mathrm{~h}$ & $\begin{array}{l}\left.\mathrm{Q}_{(24}^{\mathrm{e}} \mathrm{h}\right): \sim 1.0 \mathrm{~g} / \mathrm{Lh} \\
\text { No reference fermentation }\end{array}$ & Sugar, decrease: $\sim 33 \%^{f}$ & \\
\hline \multirow[t]{3}{*}{ Spruce hydrolysate. S. cerevisiae } & $\begin{array}{l}\mathrm{Ca}(\mathrm{OH})_{2} \mathrm{pH} 12,60^{\circ} \mathrm{C} \\
170 \mathrm{~h}\end{array}$ & $\begin{array}{l}\left.\mathrm{Q}_{(24}^{\mathrm{e}} \mathrm{h}\right): \sim 0.3 \mathrm{~g} / \mathrm{Lh} \\
\text { No reference fermentation }\end{array}$ & $\begin{array}{l}\text { Furan aldehydes, decrease: } ~ 100 \% \\
\text { Phenols, increase: } \sim 150 \% \\
\text { Sugar, decrease: } \sim 68 \%{ }^{9}\end{array}$ & {$[100]$} \\
\hline & $\mathrm{Ca}(\mathrm{OH})_{2} \mathrm{pH} 11,25^{\circ} \mathrm{C}, 20 \mathrm{~h}$ & $\begin{array}{l}\mathrm{Q}_{(24 \mathrm{~h}):}^{\mathrm{e}} \sim 0 \mathrm{~g} / \mathrm{Lh} \\
\mathrm{Q}_{(48 \mathrm{~h})}^{\mathrm{e}}: \sim 0.3 \mathrm{~g} / \mathrm{Lh}\end{array}$ & $\begin{array}{l}\text { Furan aldehydes, decrease: } \sim 77 \% \\
\text { Phenols, decrease: } \sim 8 \%\end{array}$ & \\
\hline & & No reference fermentation & Sugar, decrease: $<5 \%^{9}$ & \\
\hline \multirow[t]{2}{*}{ Bagasse hydrolysate. S. cerevisiae } & $\mathrm{Ca}(\mathrm{OH})_{2} \mathrm{pH} 10,1 \mathrm{~h}$ & $\begin{array}{l}\mathrm{BEY}=92 \% \\
B E Y^{\mathrm{a}}\left(\text { untreated }^{\mathrm{b}}\right)=68 \%\end{array}$ & $\begin{array}{l}\text { Furan aldehydes, decrease: }>25 \% \\
\text { Phenols, decrease: } \sim 17 \%\end{array}$ & [43] \\
\hline & & $\mathrm{BEY}^{\mathrm{a}}\left(\right.$ reference $\left.{ }^{\mathrm{c}}\right)=100 \%$ & Sugar, decrease: $\sim 1 \%^{\mathrm{f}}$ & \\
\hline \multirow[t]{2}{*}{ Spruce hydrolysate. S. cerevisiae } & $\mathrm{Ca}(\mathrm{OH})_{2} \mathrm{pH} 11,30^{\circ} \mathrm{C}, 3 \mathrm{~h}$ & $\begin{array}{l}\mathrm{BEY}^{\mathrm{a}}=120 \% \\
\mathrm{BEY}^{\mathrm{a}}\left(\text { untreated }^{\mathrm{b}}\right)=5 \%\end{array}$ & $\begin{array}{l}\text { Furan aldehydes, decrease: } 59 \% \\
\text { Phenols, decrease: } \sim 22 \%\end{array}$ & [49] \\
\hline & & $\mathrm{BEY}^{\mathrm{a}}\left(\right.$ reference $\left.^{\mathrm{c}}\right)=100 \%$ & Sugar, decrease: $\sim 14 \%^{\mathrm{h}}$ & \\
\hline \multirow[t]{2}{*}{ Spruce hydrolysate. S. cerevisiae } & $\mathrm{NH}_{4} \mathrm{OH} \mathrm{pH} 10,22^{\circ} \mathrm{C}, 3 \mathrm{~h}$ & $\begin{array}{l}\mathrm{BEY}^{\mathrm{a}}=110 \% \\
\mathrm{BEY}^{\mathrm{a}}\left(\text { untreated }^{\mathrm{b}}\right)=10 \%\end{array}$ & Not determined & {$[76]$} \\
\hline & & $\mathrm{BEY}^{\mathrm{a}}\left(\right.$ reference $\left.^{\mathrm{c}}\right)=100 \%$ & & \\
\hline \multirow[t]{4}{*}{ Spruce hydrolysate. S. cerevisiae } & $\mathrm{NaOH}$ pH 9, 55 $\mathrm{C}, 3 \mathrm{~h}$ & $\begin{array}{l}\mathrm{BEY}^{\mathrm{a}}=111 \% \\
\mathrm{BEY}^{\mathrm{a}}\left(\text { untreated }^{\mathrm{b}}\right)=6 \%\end{array}$ & $\begin{array}{l}\text { Furan aldehydes, decrease: } ~ 33 \% \\
\text { Phenols, decrease: } \sim 12 \%\end{array}$ & {$[77]$} \\
\hline & & $\mathrm{BE} \mathrm{Y}^{\mathrm{a}}($ reference $\mathrm{c})=100 \%$ & Sugar, decrease: $\sim 9 \%^{\mathrm{d}}$ & \\
\hline & $\mathrm{NH}_{4} \mathrm{OH} \mathrm{pH} 9,55^{\circ} \mathrm{C}, 3 \mathrm{~h}$ & $\begin{array}{l}\mathrm{BEY} Y^{\mathrm{a}}=120 \% \\
\mathrm{BEY}^{\mathrm{a}}\left(\text { untreated }^{\mathrm{b}}\right)=7 \%\end{array}$ & $\begin{array}{l}\text { Furan aldehydes, decrease: 33\% } \\
\text { Phenols, decrease: } \sim 13 \%\end{array}$ & \\
\hline & & $\mathrm{BEY}^{\mathrm{a}}\left(\right.$ reference $\left.^{\mathrm{c}}\right)=100 \%$ & Sugar, decrease: $\sim 7 \%^{\mathrm{d}}$ & \\
\hline \multirow[t]{3}{*}{ Corn stover hydrolysate. Z. mobilis } & $\mathrm{Ca}(\mathrm{OH})_{2} \mathrm{pH} 9,50^{\circ} \mathrm{C}, 0.5 \mathrm{~h}$ & $\begin{array}{l}\text { No reference fermentation. } \\
\mathrm{OEY}^{\mathrm{i}}=62 \%\end{array}$ & Sugar, decrease: 7\% & [101] \\
\hline & $\mathrm{Ca}(\mathrm{OH})_{2} \mathrm{pH} 10,50^{\circ} \mathrm{C}, 0.5 \mathrm{~h}$ & 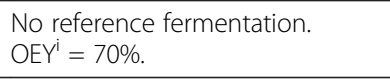 & Sugar, decrease: $~ 13 \%$ & \\
\hline & $\mathrm{Ca}(\mathrm{OH})_{2} \mathrm{pH} 11,50^{\circ} \mathrm{C}, 0.5 \mathrm{~h}$ & $\begin{array}{l}\text { No reference fermentation. } \\
\mathrm{OEY}^{\mathrm{i}}=59 \%\end{array}$ & Sugar, decrease: $\sim 29 \%{ }^{j}$ & \\
\hline
\end{tabular}

\footnotetext{
${ }^{a}$ Balanced ethanol yield given in percent of a reference fermentation of a sugar solution. ${ }^{\mathrm{b}}$ Untreated hydrolysate. ${ }^{\mathrm{c}}$ Reference sugar solution. ${ }^{\mathrm{d}}$ Glucose, xylose,

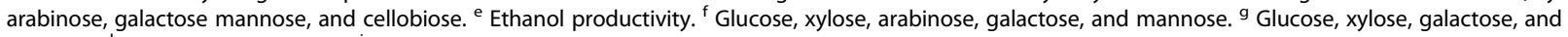
mannose. ${ }^{\mathrm{h}}$ Glucose and mannose. ${ }^{\mathrm{i}}$ Overall ethanol yield, yield calculated on sugars present prior to detoxification, given in percent of the theoretical yield. j Glucose, xylose, and arabinose.
} 
frequently studied options for detoxifying hydrolysates or slurries, the focus of this section will be detoxification by addition of alkali or other chemical agents. In comparisons of detoxification methods, treatment with calcium hydroxide (overliming) has emerged as one of the most efficient methods [33,75]. In many cases, overliming also seems to be the most economical choice [78]. Although biotechnical methods (reviewed in [74,96]) are very promising in a longer perspective, they are seldom compared to conventional methods, such as alkaline detoxification. A comparison between the performance of a hyperresistant $S$. cerevisiae transformant overexpressing Yap1 [95] and the effect of alkaline detoxification is shown in Figure 2. The result indicates that both approaches have a very clear positive impact, but only the fermentation after alkaline detoxification reaches a similar level as that of the reference fermentation.

Overliming of hydrolysates produced by pretreatment of lignocellulose with sulfuric acid results in the precipitation of calcium sulfate (gypsum) [76,97]. This keeps the concentration of soluble salts at a low level, which is favorable for the fermentation process [76,97]. However, treatment of hydrolysates with other types of alkali, such as ammonium hydroxide, can result in a fermentability that is equal to or even better than that of hydrolysates treated with overliming [76].

Although the mechanism of overliming is still not completely elucidated, considerable progress has been made. Van Zyl et al. [98] suggested that the detoxification effect of overliming was due to precipitation of toxic substances. Persson et al. [35] collected and analyzed precipitated material as well as the chemical composition of alkalitreated hydrolysates and concluded that the detoxification effect was due to chemical conversion rather than to removal of precipitated inhibitors. Furthermore, a comparison of different types of alkali for treatment of hydrolysates showed that it was possible to obtain an excellent ethanol yield (better than in a reference fermentation with similar sugar content but without inhibitors) after treatment with sodium hydroxide [77]. Since the treatment with sodium hydroxide did not give rise to any precipitate, this finding confirmed the conclusions drawn regarding the effects of alkaline treatment [35].

A problem associated with alkali detoxification is that not only inhibitors are affected by the treatment, but also the sugars, which could lead to reduced ethanol yields (Table 2). Nilvebrant et al. [99] studied the effects of treatment time, temperature, and $\mathrm{pH}$ during alkali treatment of a spruce hydrolysate. During treatment with alkali, xylose was slightly more easily degraded than the other monosaccharides. Using similar conditions (time period, $\mathrm{pH}$, and temperature), the effect of calcium hydroxide was larger than that of sodium hydroxide. More extensive sugar degradation during alkaline treatment by overliming can be attributed to the stabilisation of reactive enolate intermediates by calcium ions (Figure 3). The examples in Table 2 indicate that too harsh conditions result in extensive sugar degradation, which also has an adverse effect on ethanol production. However, it is also evident that a considerable improvement of the fermentability can be gained with a very small loss of sugar (about 1\%) (Table 2) indicating that sugar loss is not always a valid objection to alkaline detoxification.

Ethanol production is often reported as the overall ethanol yield (OEY, i.e. the yield calculated on the sugar content of the hydrolysate prior to detoxification and given in percent of the maximum theoretical yield) (Table 2). However, OEY does not take the relative fermentation improvement and the fermentation rate into account. A high OEY can be achieved after an intolerably long fermentation time. Since it is difficult to evaluate the significance of the improvement in fermentability without having a reference fermentation to relate it to, it is highly recommended that reference fermentations without inhibitors should be included in detoxification studies. One possibility is to evaluate the treatment on basis of the balanced ethanol yield (BEY) (Table 2) [76]. BEY is the amount of ethanol produced divided by the total amount

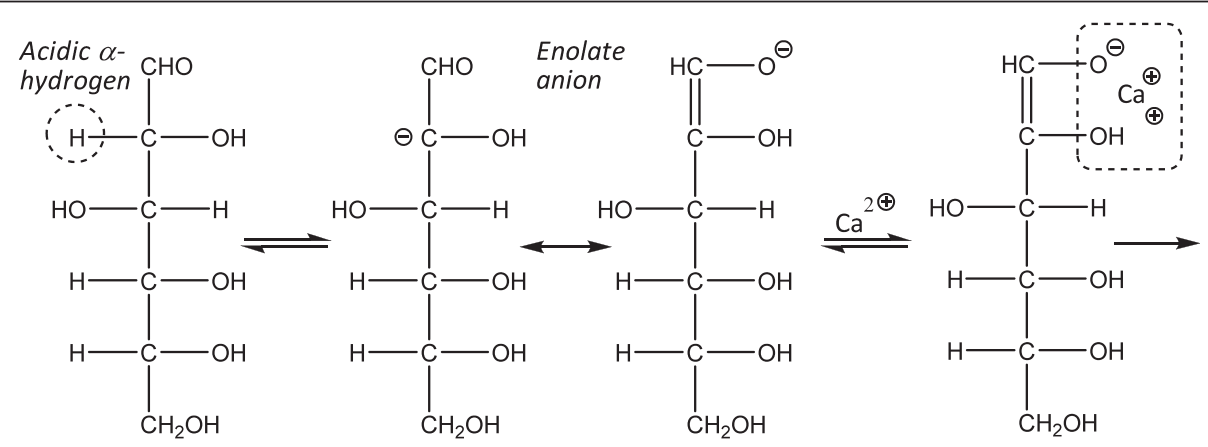

Figure 3 Monosaccharide degradation in alkali. Initial phase of degradation of glucose during alkaline treatment. Calcium ions stabilize the reactive enol intermediate, which in turn is degraded to HMF, and further to formic and levulinic acids. 
of fermentable sugars present in the hydrolysate prior to the detoxification given as percent of a reference fermentation of a sugar solution without inhibitors.

A new development in chemical detoxification is the possibility to perform the treatment in situ in the bioreactor by using reducing agents, such as sulfur oxyanions or sulfhydryl reagents [39]. Reducing agents eliminate the need for an extra process step for detoxification. Furthermore, treatment with reducing agents also decreases problems with inhibition of enzymatic hydrolysis [102]. The mechanism behind treatment with sulfur oxyanions such as bisulfite and dithionite was studied by Cavka et al. [61], who found that the effect was due to sulfonation of inhibitors, which rendered them unreactive and highly hydrophilic. The substances that are sulfonated by sulfur oxyanions include phenolics [61], which is noteworthy considering indications that phenolics play a role in the inhibition of enzymatic saccharification of cellulose $[21,46]$.

\section{Conclusions}

Acid-catalyzed thermochemical pretreatment of lignocellulosic feedstocks has several advantages: it is a simple and inexpensive approach for pretreatment that efficiently improves the susceptibility to cellulolytic enzymes, even for more recalcitrant types of lignocellulose. A drawback is the formation of by-products that inhibit enzymes and microorganisms in subsequent biocatalytic conversion steps. However, rapid progress in several areas, such as conditioning or detoxification of slurries and hydrolysates, fermentation technology, and microbial resistance to inhibitors, makes acid pretreatment into a highly competitive future alternative in the bioconversion of lignocellulosic feedstocks. Management of inhibition problems is likely to become more important in a development that favors flexibility with respect to feedstocks, processes based on high drymatter content and high product concentrations, and recirculation of process water.

\section{Competing interests}

$\mathrm{LJ}$ and BA are co-authors on patent applications on detoxification.

\section{Authors' contributions}

LJ conceptualized, researched and wrote most of the manuscript. BA researched and wrote parts of the manuscript. NON conceptualized and critically revised the manuscript, and made most of the figures. All authors read and approved the final manuscript.

\section{Acknowledgements}

This work was supported by the Bio4Energy research initiative (www. bio4energy.se), the Swedish Energy Agency (P35367-1), the Swedish Research Council (621-2011-4388), and the Biorefinery of the Future (www. bioraffinaderi.se).

\footnotetext{
Author details

'Department of Chemistry, Umeå University, Umeå SE-901 87, Sweden. ${ }^{2}$ Processum Biorefinery Initiative AB, Örnsköldsvik SE-891 22, Sweden.

${ }^{3}$ Borregaard, Sarpsborg 1701, Norway.
}

Received: 5 November 2012 Accepted: 16 January 2013

Published: 28 January 2013

\section{References}

1. Ragauskas AJ, Williams CK, Davison BH, Britovsek G, Cairney J, Eckert CA, Frederick WJ Jr, Hallett JP, Leak DJ, Liotta CL, Mielenz JR, Murphy R, Templer $R$, Tschaplinski T: The path forward for biofuels and biomaterials. Science 2006, 311:484-489.

2. Lynd LR, Laser MS, Bransby D, Dale BE, Davison B, Hamilton R, Himmel M, Keller M, McMillan JD, Sheehan J, Wyman CE: How biotech can transform biofuels. Nat Biotechnol 2008, 26:169-172.

3. Sims REH, Mabee W, Saddler JN, Taylor M: An overview of second generation biofuel technologies. Bioresour Technol 2010, 101:1570-1580.

4. Metzger JO, Hüttermann A: Sustainable global energy supply based on lignocellulosic biomass from afforestation of degraded areas. Naturwissenschaften 2009, 96:279-288.

5. Wyman CE: What is (and is not) vital to advancing cellulosic ethanol. Trends Biotechnol 2007, 25:153-157.

6. Sjöström E, Alén R (Eds): Analytical methods in wood chemistry, pulping, and papermaking. Berlin, Heidelberg: Springer-Verlag; 1999.

7. Rowell RM: Handbook of wood chemistry and wood composites. 2nd edition. Boca Raton FL: CRC Press; 2012

8. Mabee WE, Gregg DJ, Arato C, Berlin A, Bura R, Gilkes N, Mirochnik O, Pan X, Pye EK, Saddler JN: Updates on softwood-to-ethanol process development. Appl Biochem Biotechnol 2006, 129-132:55-70.

9. Galbe M, Zacchi G: Pretreatment of lignocellulosic materials for efficient bioethanol production. Adv Biochem Eng Biotechnol 2007, 108:41-65.

10. Cullis IF, Mansfield SD: Optimized delignification of wood-derived lignocellulosics for improved enzymatic hydrolysis. Biotech Bioeng 2010, 106:884-893.

11. Shuai L, Yang Q, Zhu JY, Lu FC, Weimer PJ, Ralph J, Pan XJ: Comparative study of SPORL and dilute-acid pretreatments of spruce for cellulosic ethanol production. Bioresour Technol 2010, 101:3106-3114.

12. Arantes $V$, Saddler JN: Cellulose accessibility limits the effectiveness of minimum cellulase loading on the efficient hydrolysis of pretreated lignocellulosic substrates. Biotechnol Biofuels 2011, 4:3.

13. Viikari L, Alapuranen M, Puranen T, Vehmaanperä J, Siika-Aho M: Thermostable enzymes in lignocellulose hydrolysis. Adv Biochem Eng Biotechnol 2007, 108:121-145.

14. Arantes $V$, Saddler JN: Access to cellulose limits the efficiency of enzymatic hydrolysis: the role of amorphogenesis. Biotechnol Biofuels 2010, 3:4.

15. Van Zyl WH, Lynd LR, den Haan R, McBride JE: Consolidated bioprocessing for bioethanol production using Saccharomyces cerevisiae. Adv Biochem Eng Biotechnol 2007, 108:205-235

16. Dunlop MJ: Engineering microbes for tolerance to nextgeneration biofuels. Biotechnol Biofuels 2011, 4:32.

17. Teixeira MC, Godinho CP, Cabrito TR, Mira NP, Sá-Correia I: Increased expression of the yeast multidrug resistance $A B C$ transporter Pdr18 leads to increased ethanol tolerance and ethanol production in high gravity alcoholic fermentation. Microb Cell Fact 2012, 11:98.

18. Andrić P, Meyer AS, Jensen PA, Dam-Johansen K: Reactor design for minimizing product inhibition during enzymatic lignocellulose hydrolysis: I. Significance and mechanism of cellobiose and glucose inhibition on cellulolytic enzymes. Biotechnol Adv 2010, 28:308-324.

19. Podkaminer KK, Shao X, Hogsett DA, Lynd LR: Enzyme inactivation by ethanol and development of a kinetic model for thermophilic simultaneous saccharification and fermentation at $50^{\circ} \mathrm{C}$ with Thermoanaerobacterium saccharolyticum ALK2. Biotech Bioeng 2011, 108:1268-1278.

20. Bezerra RMF, Dias AA: Enzymatic kinetic of cellulose hydrolysis - Inhibition by ethanol and cellobiose. Appl Biochem Biotechnol 2005, 126:49-59.

21. Ximenes E, Kim Y, Mosier N, Dien B, Ladisch M: Inhibition of cellulases by phenols. Enzyme Microb Tech 2010, 46:170-176.

22. Martín C, Galbe M, Nilvebrant N-O, Jönsson L: Comparison of the fermentability of enzymatic hydrolysates of sugarcane bagasse pretreated by steam explosion using different impregnating agents. Appl Biochem Biotechnol 2002, 98-100:699-716.

23. Popoff $T$, Theander $\mathrm{O}$ : Formation of aromatic compounds from carbohydrates: Part III. Reaction of D-glucose and D-fructose in slightly acidic, aqueous solution. Acta Chem Scand 1976, 30:397-402. 
24. Fenske JJ, Griffin DA, Penner MH: Comparison of aromatic monomers in lignocellulosic biomass prehydrolysates. J Ind Microbiol Biotechnol 1998, 20:364-368

25. Chen SF, Mowery RA, Scarlata CJ, Chambliss CK: Compositional analysis of water-soluble materials in corn stover. J Agric Food Chem 2007, 55:5912-5918.

26. Du B, Sharma LN, Becker C, Chen S-F, Mowery RA, van Walsum GP, Chambliss CK: Effect of varying feedstock-pretreatment chemistry combinations on the formation and accumulation of potentially inhibitory degradation products in biomass hydrolysates. Biotech Bioeng 2010, 107:430-440.

27. Tran AV, Chambers RP: Red oak derived inhibitors in the ethanol fermentation of xylose by Pichia stipitis CBS 5776. Biotechnol Lett 1985, 7:841-845.

28. Clark TA, Mackie KL: Fermentation inhibitors in wood hydrolysates derived from the softwood Pinus radiata. J Chem Tech Biotechnol 1984, 34:101-110

29. Tran AV, Chambers RP: Lignin and extractives derived inhibitors in the 2,3-butanediol fermentation of mannose-rich prehydrolysates. Appl Microbiol Biotechnol 1986, 23:191-197.

30. Ando S, Arai I, Kiyoto K, Hanai S: Identification of aromatic monomers in steam-exploded poplar and their influences on ethanol fermentation by Saccharomyces cerevisiae. J Ferment Technol 1986, 64:567-570.

31. Burtscher E, Bobleter O, Schwald W, Concin R, Binder H: Chromatographic analysis of biomass reaction products produced by hydrothermolysis of poplar wood. J Chromatogr 1987, 390:401-412.

32. Luo C, Brink DL, Blanch HW: Identification of potential fermentation inhibitors in conversion of hybrid poplar hydrolysate to ethanol. Biomass Bioenergy 2002, 22:125-138.

33. Larsson S, Reimann A, Nilvebrant N-O, Jönsson LJ: Comparison of different methods for the detoxification of lignocellulose hydrolysates of spruce. Appl Biochem Biotechnol 1999, 77:91-103.

34. Persson P, Larsson S, Jönsson LJ, Nilvebrant N-O, Sivik B, Munteanu F, Thörneby L, Gorton L: Supercritical fluid extraction of a lignocellulosic hydrolysate of spruce for detoxification and to facilitate analysis of inhibitors. Biotech Bioeng 2002, 79:694-700.

35. Persson P, Andersson J, Gorton L, Larsson S, Nilvebrant N-O, Jönsson L: Effect of different forms of alkali treatment on specific fermentation inhibitors and on the fermentability of lignocellulose hydrolysates for production of fuel ethanol. J Agric Food Chem 2002, 50:5318-5325.

36. Jönsson LJ, Palmqvist $\mathrm{E}$, Nilvebrant N-O, Hahn-Hägerdal B: Detoxification of wood hydrolysates with laccase and peroxidase from the white-rot fungus Trametes versicolor. Appl Microbiol Biotechnol 1998, 49:691-697.

37. Klinke HB, Ahring BA, Schmidt AS, Thomsen AB: Characterization of degradation products from alkaline wet oxidation of wheat straw. Bioresour Technol 2002, 82:15-26.

38. Nilvebrant N-O, Reimann A, Larsson S, Jönsson LJ: Detoxification of lignocellulose hydrolysates with ion-exchange resins. App/ Biochem Biotechnol 2001, 91-93:35-49.

39. Alriksson B, Cavka A, Jönsson LJ: Improving the fermentability of enzymatic hydrolysates of lignocellulose through chemical in-situ detoxification with reducing agents. Bioresour Technol 2011, 102:1254-1263.

40. Lowry GH, Rosebrough NJ, Farr AL, Randall RJ: Protein measurement with the Folin phenol reagent. J Biol Chem 1951, 193:265-275.

41. Larsson S, Quintana-Sáinz A, Reimann A, Nilvebrant N-O, Jönsson LJ: Influence of lignocellulose-derived aromatic compounds on oxygenlimited growth and ethanolic fermentation by Saccharomyces cerevisiae. Appl Biochem Biotechnol 2000, 84:617-632.

42. Keweloh H, Weyrauch $\mathrm{G}$, Rehm H-J: Phenol-induced membrane changes in free and immobilized Escherichia coli. Appl Microbiol Biotechnol 1990 33:66-71.

43. Martín C, Galbe M, Wahlbom CF, Hahn-Hägerdal B, Jönsson LJ: Ethanol production from enzymatic hydrolysates of sugarcane bagasse using recombinant xylose-utilising Saccharomyces cerevisiae. Enzyme Microb Tech 2002, 31:274-282.

44. Chandel AK, Kapoor RK, Singh A, Kuhad RC: Detoxification of sugarcane bagasse hydrolysate improves ethanol production by Candida shehatae NCIM 3501. Bioresour Technol 2007, 98:1947-1950.

45. Jurado M, Prieto A, Martínez-Alcalá A, Martínez AT, Martínez MJ: Laccase detoxification of steam-exploded wheat straw for second generation bioethanol. Bioresour Technol 2009, 100:6378-6384.
46. Kim Y, Ximenes E, Mosier NS, Ladisch MR: Soluble inhibitors/deactivators of cellulase enzymes from lignocellulosic biomass. Enzyme Microb Tech 2011, 48:408-415.

47. Ulbricht RJ, Sharon J, Thomas J: A review of 5-hydroxymethylfurfural HMF in parental solutions. Fund App/ Toxicol 1984, 4:843-853.

48. Larsson S, Palmqvist E, Hahn-Hägerdal B, Tengborg C, Stenberg K, Zacchi G, Nilvebrant $\mathrm{N}-\mathrm{O}$ : The generation of fermentation inhibitors during dilute acid hydrolysis of softwood. Enzyme Microb Tech 1999, 24:151-159.

49. Sárvári Horváth I, Sjöde A, Alriksson B, Jönsson LJ, Nilvebrant N-O: Critical conditions for improved fermentability during overliming of acid hydrolysates from spruce. Appl Biochem Biotechnol 2005, 121-124:1031-1044

50. Pampulha ME, Loureiro-Dias MC: Combined effect of acetic acid, $\mathrm{pH}$ and ethanol on intracellular $\mathrm{pH}$ of fermenting yeast. Appl Microbiol Biotechno 1989, 31:547-550

51. Verduyn C, Postma E, Scheffers WA, Van Dijken JP: Physiology of Saccharomyces cerevisiae in anaerobic glucose-limited chemostat cultures. J Gen Microbiol 1990, 136:305-319.

52. Viegas CA, Sá-Correia I: Activation of plasma membrane ATPase of Saccharomyces cerevisiae by octanoic acid. J Gen Microbiol 1991, 137:645-651.

53. Verduyn C, Postma E, Scheffers WA, Van Dijken JP: Effect of benzoic acid on metabolic fluxes in yeast: a continuous-culture study on the regulation of respiration and alcoholic fermentation. Yeast 1992, 8:501-517.

54. Norman C, Howell KA, Millar AH, Whelan JM, Day DA: Salicylic acid is an uncoupler and inhibitor of mitochondrial electron transport. Plant Physiol 2004, 134:492-501.

55. Chung IS, Lee YY: Ethanol fermentation of crude acid hydrolyzate of cellulose using high-level yeast inocula. Biotech Bioeng 1985, 27:308-315.

56. Liu ZL, Slininger PJ, Dien BS, Berhow MA, Kurtzman CP, Gorsich SW: Adaptive response of yeast to furfural and 5-hydroxymethylfurfural and new chemical evidence for HMF conversion to 2,5-bishydroxymethylfuran. J Ind Microbiol Biotechnol 2004, 31:345-352.

57. Diaz De Villegas ME, Villa P, Guerra M, Rodríguez E, Redondo D, Martinez A Conversion of furfural into furfuryl alcohol by Saccharomyces cerevisiae. Acta Biotechnol 1992, 12:351-354.

58. Sárvári Horváth I, Franzén CJ, Taherzadeh MJ, Niklasson C, Lidén G: Effects of furfural on the respiratory metabolism of Saccharomyces cerevisiae in glucose-limited chemostats. Appl Environ Microbiol 2003, 69:4076-4086.

59. Taherzadeh MJ, Gustafsson L, Niklasson C, Lidén G: Physiological effects of 5-hydroxymethylfurfural on Saccharomyces cerevisiae. Appl Microbiol Biotechnol 2000, 53:701-708.

60. Wahlbom CF, Hahn-Hägerdal B: Furfural, 5-hydroxymethyl furfural, and acetoin act as external electron acceptors during anaerobic fermentation of xylose in recombinant Saccharomyces cerevisiae. Biotech Bioeng 2002, 78:172-178.

61. Cavka A, Alriksson B, Ahnlund M, Jönsson LJ: Effect of sulfur oxyanions on lignocellulose-derived fermentation inhibitors. Biotech Bioeng 2011, 108:2592-2599.

62. Martinez A, Rodriguez ME, York SW, Preston JF, Ingram LO: Effects of Ca $(\mathrm{OH})_{2}$ treatments ("overliming") on the composition and toxicity of bagasse hemicellulose hydrolysates. Biotech Bioeng 2000, 69:526-536.

63. Liu ZL: Molecular mechanisms of yeast tolerance and in situ detoxification of lignocellulose hydrolysates. Appl Microbiol Biotechnol 2011, 90:809-825.

64. Wadskog I, Adler L: Ion homeostasis in Saccharomyces cerevisiae under $\mathrm{NaCl}$ stress. In Yeast stress response. Edited by Hohmann S, Mager WH. Berlin: Springer-Verlag; 2003:201-240.

65. Helle S, Cameron D, Lam J, White B, Duff S: Effect of inhibitory compounds found in biomass hydrolysates on growth and xylose fermentation by a genetically engineered strain of S. cerevisiae. Enzyme Microb Tech 2003, 33:786-792

66. Maiorella BL, Blanch HW, Wilke CR: Feed component inhibition in ethanolic fermentation by Saccharomyces cerevisiae. Biotech Bioeng 1984 26:1155-1166.

67. Alexandre $\mathrm{H}$, Charpentier $\mathrm{C}$ : Biochemical aspects of stuck and sluggish fermentation in grape must. J Ind Microbiol Biot 1998, 20:20-27.

68. Lin $Y$, Tanaka S: Ethanol fermentation from biomass resources: current state and prospects. Appl Microbiol Biotechnol 2006, 69:627-642. 
69. Palmqvist E, Grage H, Meinander NQ, Hahn-Hägerdal B: Main and interaction effects of acetic acid, furfural, and $p$-hydroxybenzoic acid on growth and ethanol productivity of yeasts. Biotech Bioeng 1999, 63:46-55.

70. Zaldivar J, Ingram LO: Effect of organic acids on the growth and fermentation of ethanologenic Escherichia coli LY01. Biotech Bioeng 1999, 66:203-210.

71. Klinke HB, Olsson L, Thomsen AB, Ahring BK: Potential inhibitors from we oxidation of wheat straw and their effect on ethanol production of Saccharomyces cerevisiae: wet oxidation and fermentation by yeast. Biotech Bioeng 2003, 81:738-747.

72. Olofsson K, Bertilsson M, Lidén G: A short review on SSF - an interesting process option for ethanol production from lignocellulosic feedstocks. Biotechnol Biofuels 2008, 1:7.

73. Pienkos PT, Zhang M: Role of pretreatment and conditioning processes on toxicity of lignocellulosic biomass hydrolysates. Cellulose 2009, 16:743-762

74. Parawira W, Tekere M: Biotechnological strategies to overcome inhibitors in lignocellulose hydrolysates for ethanol production: review. Crit Rev Biotechnol 2011, 31:20-31.

75. Cantarella M, Cantarella L, Gallifuoco A, Spera A, Alfani F: Comparison of different detoxification methods for steam-exploded poplar wood as a substrate for the bioproduction of ethanol in SHF and SSF. Proc Biochem 2004, 39:1533-1542.

76. Alriksson B, Sjöde A, Sárvári Horváth I, Nilvebrant N-O, Jönsson LJ: Ammonium hydroxide detoxification of spruce acid hydrolysates. Appl Biochem Biotechnol 2005, 121-124:911-922.

77. Alriksson B, Sjöde A, Nilvebrant N-O, Jönsson L: Optimal conditions for alkaline detoxification of dilute-acid lignocellulose hydrolysates. Appl Biochem Biotechnol 2006, 129-132:599-611.

78. Ranatunga TD, Jervis J, Helm RF, McMillan JD, Wooley RJ: The effect of overliming on the toxicity of dilute acid pretreated lignocellulosics: The role of inorganics, uronic acids and ether-soluble organics. Enzyme Microb Tech 2000, 27:240-247.

79. Zhu J, Yong Q, Xu Y, Yu S: Detoxification of corn stover prehydrolyzate by trialkylamine extraction to improve the ethanol production with Pichia stipitis CBS 5776. Bioresour Technol 2011, 102:1663-1668.

80. Parajó JC, Dominguez H, Domínguez JM: Improved xylitol production with Debaryomyces hansenii Y-7426 from raw or detoxified wood hydrolysates. Enzyme Microb Tech 1997, 21:18-24.

81. Sárvári Horváth I, Sjöde A, Nilvebrant N-O, Zagorodni A, Jönsson LJ: Selection of anion exchangers for detoxification of dilute-acid hydrolysates from spruce. App/ Biochem Biotechnol 2004, 114:525-538.

82. Björklund L, Larsson S, Jönsson LJ, Reimann A, Nilvebrant N-O: Treatment with lignin residue - a novel method for detoxification of lignocellulose hydrolysates. Appl Biochem Biotechnol 2002, 98-100:563-575.

83. López MJ, Nichols NN, Dien BS, Moreno J, Bothast RJ: Isolation of microorganisms for biological detoxification of lignocellulosic hydrolysates. Appl Microbiol Biotechnol 2004, 64:125-131.

84. Nichols NN, Sharma LN, Mowery RA, Chambliss CK, van Walsum GP, Dien $B S$, Iten LB: Fungal metabolism of fermentation inhibitors present in corn stover dilute acid hydrolysate. Enzyme Microb Tech 2008, 42:624-630.

85. Palmqvist E, Hahn-Hägerdal B, Szengyel Z, Zacchi G, Rèczey K: Simultaneous detoxification and enzyme production of hemicellulose hydrolysates obtained after steam pretreatment. Enzyme Microb Tech 1997, 20:286-293.

86. Okuda N, Soneura M, Ninomiya K, Katakura Y, Shioya S: Biological detoxification of waste house wood hydrolysate using Ureibacillus thermosphaericus for bioethanol production. J Biosci Bioeng 2008, 106:128-133.

87. Wingren A, Galbe M, Zacchi G: Techno-economic evaluation of producing ethanol from softwood: comparison of SSF and SHF and identification of bottlenecks. Biotechnol Prog 2003, 19:1109-1117.

88. Wingren A, Galbe M, Roslander C, Rudolf A, Zacchi G: Effect of reduction in yeast and enzyme concentrations in a simultaneous-saccharificationand-fermentation-based bioethanol process. Appl Biotechnol Biochem 2005, 122:485-500.

89. Larsson S, Cassland P, Jönsson LJ: Development of a Saccharomyces cerevisiae strain with enhanced resistance to phenolic fermentation inhibitors in lignocellulose hydrolysates by heterologous expression of laccase. Appl Environ Microbiol 2001, 67:1163-1170.
90. Larsson S, Nilvebrant N-O, Jönsson LJ: Effect of overexpression of Saccharomyces cerevisiae Pad1p on the resistance to phenylacrylic acid and lignocellulose hydrolysates under aerobic and oxygen-limited conditions. Appl Microbiol Biotechnol 2001, 57:167-174.

91. Petersson A, Almeida JRM, Modig T, Karhumaa K, Hahn-Hägerdal B, Gorwa-Grauslund MF, Lidén G: A 5-hydroxymethyl furfural reducing enzyme encoded by the Saccharomyces cerevisiae ADH6 gene conveys HMF tolerance. Yeast 2006, 23:455-464.

92. Gorsich SW, Dien BS, Nichols NN, Slininger PJ, Liu ZL, Skory CD: Tolerance to furfural-induced stress is associated with pentose phosphate pathway genes ZWF1, GND1, RPE1, and TKL1 in Saccharomyces cerevisiae. Appl Microbiol Biotechnol 2006, 71:339-349.

93. Hasunuma T, Sanda T, Yamada R, Yoshimura K, Ishii J, Kondo A: Metabolic pathway engineering based on metabolomics confers acetic and formic acid tolerance to a recombinant xylose-fermenting strain of Saccharomyces cerevisiae. Microb Cell Fact 2011, 10:2.

94. Hasunuma T, Sung K, Sanda T, Yoshimura K, Matsuda F, Kondo A: Efficient fermentation of xylose to ethanol at high formic acid concentrations by metabolically engineered Saccharomyces cerevisiae. Appl Microbiol Biotechnol 2011, 90:997-1004

95. Alriksson B, Sárvári Horváth I, Jönsson LJ: Overexpression of Saccharomyces cerevisiae transcription factor and multidrug resistance genes conveys enhanced resistance to lignocellulose-derived fermentation inhibitors. Proc Biochem 2010, 45:264-271.

96. Nevoigt E: Progress in metabolic engineering of Saccharomyces cerevisiae. Microbiol Mol Biol Rev 2008, 72:379-412

97. Martinez A, Rodriguez ME, Wells ML, York SW, Preston JF, Ingram LO: Detoxification of dilute acid hydrolysates of lignocellulose with lime. Biotechnol Progr 2001, 17:287-293.

98. Van Zyl C, Prior BA, Du Preez JC: Production of ethanol from sugarcane bagasse hemicellulose hydrolyzate by Pichia stipitis. Appl Biochem Biotechnol 1988, 17:357-369.

99. Nilvebrant N-O, Persson P, Reimann A, de Sousa F, Gorton L, Jönsson LJ: Limits for alkaline detoxification of dilute-acid lignocellulose hydrolysates. App/ Biochem Biotechnol 2003, 105-108:615-628.

100. Millati R, Niklasson C, Taherzadeh MJ: Effect of $\mathrm{pH}$, time and temperature of overliming on detoxification of dilute-acid hydrolyzates for fermentation by Saccharomyces cerevisiae. Proc Biochem 2002, 38:515-522.

101. Mohagheghi A, Ruth M, Schnell DJ: Conditioning hemicellulose hydrolysates for fermentation: effects of overliming $\mathrm{pH}$ on sugar and ethanol yields. Proc Biochem 2006, 41:1806-1811.

102. Soudham VP, Alriksson B, Jönsson L: Reducing agents improve enzymatic hydrolysis of cellulosic substrates in the presence of pretreatment liquid. J Biotechnol 2011, 155:244-250.

doi:10.1186/1754-6834-6-16

Cite this article as: Jönsson et al:: Bioconversion of lignocellulose: inhibitors and detoxification. Biotechnology for Biofuels 2013 6:16.

\section{Submit your next manuscript to BioMed Central and take full advantage of:}

- Convenient online submission

- Thorough peer review

- No space constraints or color figure charges

- Immediate publication on acceptance

- Inclusion in PubMed, CAS, Scopus and Google Scholar

- Research which is freely available for redistribution 